\title{
Phylogeny by a polyphasic approach of the order Caulobacterales, proposal of Caulobacter mirabilis sp. nov., Phenylobacterium haematophilum sp. nov. and Phenylobacterium conjunctum sp. nov., and emendation of the genus Phenylobacterium
}

\author{
Wolf-Rainer Abraham, ${ }^{1}$ Alexandre J. Macedo, ${ }^{1} \dagger$ Heinrich Lünsdorf, ${ }^{1}$ \\ Roman Fischer, ${ }^{2}$ Sonja Pawelczyk, ${ }^{1}$ John Smit $^{3}$ and Marc Vancanneyt ${ }^{4}$ \\ ${ }^{1}$ Helmholtz Center for Infection Research (formerly GBF), Chemical Microbiology, Inhoffenstrasse \\ 7, D-38124 Braunschweig, Germany \\ ${ }^{2}$ Helmholtz Center for Infection Research, Cellular Proteomics Group, Braunschweig, Germany \\ ${ }^{3}$ University of British Columbia, Dept of Microbiology and Immunology, Vancouver, Canada \\ ${ }^{4}$ Laboratorium voor Microbiologie, Universiteit Gent, Belgium
}

Correspondence Wolf-Rainer Abraham wab@gbf.de
The genus Caulobacter was originally composed of dimorphic, prosthecate bacteria. In these prokaryotes, reproduction results in the separation of two cells that are morphologically and behaviourally different from each

tPresent address: Universidade Federal do Rio Grande do Sul, Faculdade de Farmácia, Porto Alegre, RS, Brazil.

Abbreviations: CID, collision-induced dissociation; FAB-MS, fast atom bombardment mass spectrometry; PG, phosphatidylglycerol; PGL, 3-O[6'-(sn-glycero-3"-phosphoryl)- $\alpha$-D-glucopyranosyl]-sn-glycerol.

Figures showing a phylogenetic tree constructed from 16S rRNA gene sequences using the minimal evolution algorithm and the negative fast atom bombardment mass spectra of the polar lipids are available as supplementary material with the online version of this paper. Tables detailing the cellular fatty acid contents, phospho- and sulfolipids, polar lipids, enzyme activities and the results of the Biolog tests for the species examined in this study are given in supplementary tables S1-S5, available with the online version of this paper. other. One cell is non-motile and prosthecate (Staley, 1968) and sticks to surfaces by adhesive material located at the tip of the prostheca. The other cell bears one polar flagellum by which it is motile. This mode of reproduction helps these oligotrophic bacteria to disperse the population at each generation, thereby minimizing competition for resources (Poindexter, 1981). Caulobacteria have been known for more than a century and the first isolation of a Caulobacter sp. was reported by Löffler in 1890 (Löffler, 1890). Even then, he noticed the unusual nutrient requirements of the strain due to the oligotrophic nature of the isolate. In 1935, Henrici and Johnson described the genus Caulobacter with Caulobacter vibrioides as the type species (Henrici \& Johnson, 1935) but they did not isolate C. vibrioides and therefore no type strain was given. Poindexter (1964) proposed strain CB 51 as the neotype strain of C. vibrioides and described nine species and two 
subspecies (Poindexter, 1964, Poindexter \& Lewis, 1966). By determining the 16S rRNA gene sequences of several isolates belonging to the genus Caulobacter, Stahl and coworkers revealed that the genus Caulobacter actually forms two different lineages, one comprising the freshwater and brackish water Caulobacter species and the other comprising the marine Caulobacter species (Stahl et al., 1992) now harboured by the genus Maricaulis (Abraham et al., 1999).

As caulobacteria are present in almost every water sample and are believed to play an important role in the carbon cycling within their habitats, the diversity of Caulobacter isolates was evaluated using lipid analysis, 16S rRNA gene sequences and profiling of the 16S-23S rRNA gene interspacer regions and these results were compared with physiological data. As a result, the descriptions of the genera Caulobacter and Brevundimonas were emended and a number of Caulobacter species were transferred to the genus Brevundimonas (Abraham et al. 1999). As part of an ongoing study, we identified a number of strains which could not be identified as any of the recognized species of caulobacteria. In this paper, three of the novel species that were identified from this study are described.

Strains for this study were obtained from the American Type Culture Collection (ATCC), the Deutsche Sammlung für Mikroorganismen und Zellkulturen (DSM), the Laboratorium voor Microbiologie, Universiteit Gent, Belgium, (LMG), The All-Russian Collection of Microorganisms (VKM) and from John Smit of the Department of Microbiology and Immunology of the University of British Columbia, Canada, (CB and FWC strains; Abraham et al., 1999). All strains were grown in freshwaterCaulobacter-medium PYEM containing: $2 \mathrm{~g}$ peptone, $2 \mathrm{~g}$ yeast extract, $0.5 \mathrm{~g} \mathrm{NH}_{4} \mathrm{Cl}$ and 11 Milli-Q water. After autoclaving and cooling, $5 \mathrm{ml}$ riboflavin $\left(0.2 \mathrm{mg} \mathrm{ml}^{-1}\right)$ sterile filtrated, $2 \mathrm{ml} 50 \%$ glucose (sterile), $1 \mathrm{ml} 20 \%$ $\mathrm{MgSO}_{4}$ (sterile) and $1 \mathrm{ml} 10 \% \mathrm{CaCl}_{2}$ (sterile) were added. The strains were grown in 21 flasks at $30{ }^{\circ} \mathrm{C}$ and 100 r.p.m. and the biomass was harvested in the late exponential phase after $72 \mathrm{~h}$.

For electron microscopy, mid-exponential cells were adsorbed from an aliquot to Formvar-coated 300 mesh copper grids for $5 \mathrm{~min}$ at ambient temperature. Grids then were briefly blotted, washed for $15 \mathrm{~s}$ with deionized water and were either negatively stained with $1 \%(\mathrm{w} / \mathrm{v})$ uranyl acetate, $\mathrm{pH} 4.0$, or air-dried and Pt-C shadow-cast at an angle of 10 degrees, according to Yakimov et al. (1998). For ultrathin section preparations, cells were fixed with $1.25 \%$ $(\mathrm{v} / \mathrm{v})$ glutaraldehyde in the growth medium for $1 \mathrm{~h}$ at ambient temperature and were then stored at $4{ }^{\circ} \mathrm{C}$ for five days. Cells were washed twice in $100 \mathrm{mM}$ cacodylate, $\mathrm{pH} 7.2$, post-fixed with $1 \%(\mathrm{w} / \mathrm{v})$ osmium tetroxide/ $100 \mathrm{mM}$ cacodylate, $\mathrm{pH} 7.2$ for $60 \mathrm{~min}$ at ambient temperature and were then immobilized in $1 \%(\mathrm{w} / \mathrm{v})$ agar-water and dehydrated in an ascending ethanol series. The final ethanol phase was exchanged with acetone and cells were embedded in hard grade epoxy resin (Spurr, 1969). Ultrathin sections (90 nm), negatively stained and Pt-C shadowed samples were analysed with an energyfiltered transmission electron microscope (EFTEM; CEM 902, Zeiss) at zero-loss (slit width: $20 \mathrm{eV;} \mathrm{objective}$ aperture: $30 \mu \mathrm{m}$ ) at $80 \mathrm{kV}$ in a magnification range from $\times 7000$ to $\times 85000$. Micrographs were recorded with a $1024 \times 1024$ CCD slow scan camera (CCD HSS 512/1024; Proscan Electronic Systems).

Cells of strain FWC $21^{\mathrm{T}}$ growing mid-exponentially were often organized as 'rosettes', formed by central clumping of the sticky holdfast termini (Fig. 1a). Characteristically, some prostheca showed predefined points of fissures (Fig. 1a: pf), which may help cells to dock off as mobile cells, though the general method of dispersal involves growth and diversion of polar, monotrichously flagellated daughter cells (Fig. 1a: sc). Residual prostheca are indicated (Fig. 1a: asterisks) as the remnants of offspring from the sessile state. Based on measurements of negatively stained swarming cells, cells of strain FWC $21^{T}$ were 1150 $1590 \mathrm{~nm}$ in length and $540-670 \mathrm{~nm}$ in width. The cell wall was of a Gram-negative architecture and was about $25 \mathrm{~nm}$ in width (Fig. 1b: cytoplasmic membrane-outer membrane distance), layered with an S-layer (Fig. 1b: sl) of $7.4 \mathrm{~nm}$ thickness. Contrary to strain FWC $21^{\mathrm{T}}$, cells of strain LMG $11050^{\mathrm{T}}$ did not show a stalk. As whole mount preparations, shadow-cast mid-exponential cells of strain FWC $21^{\mathrm{T}}$ appeared as short rods, measuring 620-880 nm in width (mean: $718 \pm 70.6 \mathrm{~nm} ; n=24$ ) versus 950$1500 \mathrm{~nm}$ in length (mean: $1152 \pm 155 \mathrm{~nm} ; n=18$ ). Cells were flagellated and motile with a single flagellum, polarly inserted (Fig. 2a), which measured up to $7 \mu \mathrm{m}$ in length. Apart from flagella and thin fimbriae, no further cellular appendices, such as prostheca, could be observed. A further characteristic feature of this strain was the presence of an Slayer, which could be recognized both in negatively stained (data not shown) and in Pt-C shadow-cast samples (Fig. 2c), showing a nearly orthogonal, almost square lattice and structural details down to $0.90 \mathrm{~nm}$ and $0.96 \mathrm{~nm}$ (Fig. 2b). When samples were embedded and ultrathin sections were examined (Fig. 2d), the cytoplasm was of general appearance, showing condensed chromosomal DNA within ribosomal dominated cytoplasmic matrix, which occasionally contained darkish inclusions (data not shown). At higher magnification, all the components of a Gram-negative cell wall structure were revealed.

Genomic DNA was isolated from a $2 \mathrm{ml}$ sample of cultures according to the protocol of Wilson (1987), followed by treatment with RNase A (Sigma) at $50{ }^{\circ} \mathrm{C}$ for $2 \mathrm{~h}$ and additional phenol/chloroform/isoamyl alcohol extraction. Appropriate amounts of DNA were enzymically digested and the mean guanine and cytosine $(\mathrm{G}+\mathrm{C})$ contents were determined by HPLC (Tamaoka \& Komagata, 1984). Calculations were carried out according to Mesbah et al. (1989), with non-methylated $\lambda$-phage DNA (Sigma) used as a standard. DNA G $+\mathrm{C}$ contents of $67.0 \pm 0.1 \mathrm{~mol} \%$ and $68.0 \pm 0.0 \mathrm{~mol} \%$ were determined for strain FWC $21^{\mathrm{T}}$ and 


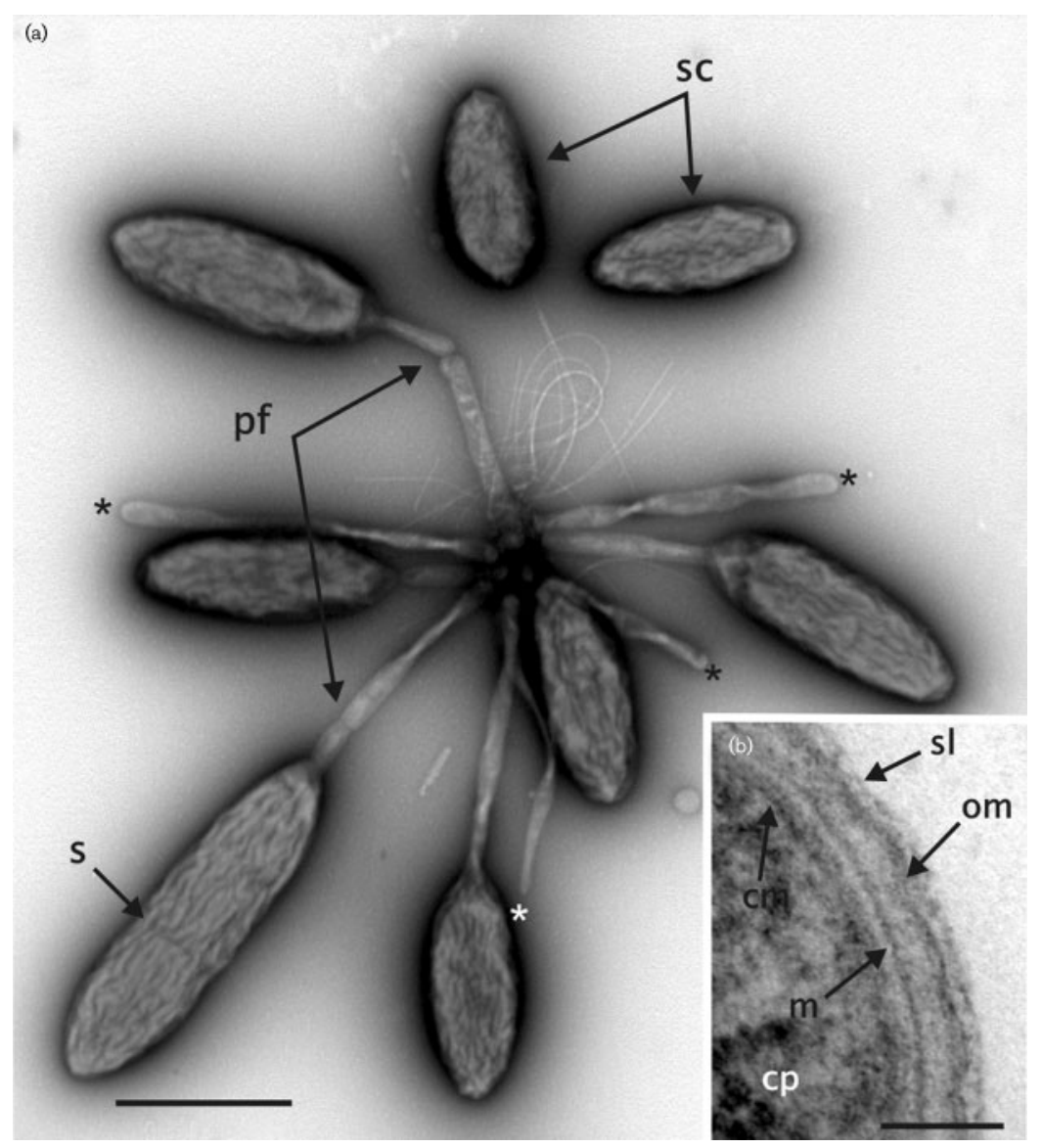

Fig. 1. Electron microscopy of cells of isolate FCW $21^{\top}$. (a) Negatively stained 'rosette' (pf, prosthecum fissure; sc, swarming cell; $\mathrm{s}$, septum; *, residual prosthecum). (b) Ultrathin section of the cell wall (sl, S-layer; $\mathrm{m}$, murein layer; om, outer membrane; cm, cytoplasmic membrane; cp, cytoplasm). Bars, $1 \mu \mathrm{m}$ (a) and $50 \mathrm{~nm}$ (b).

strain FWC $38^{\mathrm{T}}$, respectively. A value of $67.8 \mathrm{~mol} \%$ has been reported previously for strain LMG $11050^{\mathrm{T}}$ (Segers et al., 1994). These values are at the upper limit of $G+C$ values determined so far for species of the genera Brevundimonas and Caulobacter but they fit well with those reported for species of the genus Phenylobacterium (Aslam et al., 2005).

For the amplification of the 16S rRNA gene by PCR, single colonies were boiled in $100 \mu$ of TE buffer for about $10 \mathrm{~min}$ at $95{ }^{\circ} \mathrm{C}$. An almost complete $16 \mathrm{~S}$ rRNA gene sequence was obtained as described previously (Abraham et al., 1999). The reactions were evaluated on an Applied Biosystems 377 Genetic Analyzer and the final contig was assembled using the SEQUENCHER program, version 4.0.5 (Gene Codes Corporation). The sequence was matched in BLAST 2.2.9 (Altschul et al., 1990) against the EMBL database (Kanz et al., 2005). The 16S rRNA gene sequences of strains FWC $21^{\mathrm{T}}$, FWC $38^{\mathrm{T}}$ and LMG $11050^{\mathrm{T}}$ have been previously deposited at the EMBL database under the accession numbers AJ227767, AJ227774 and AJ244650, respectively. The sequences were aligned using CLUSTAL $\mathrm{W}$ software (Thompson et al., 1997). Tree topologies were reconstructed with the UPGMA algorithm with 1000 bootstrap replications (Fig. 3) and the minimal evolution algorithm was calculated with MEGA 3.1 software (Kumar et al., 2004) (see Supplementary Fig. S1 in IJSEM Online) using the EMBL database (Kanz et al., 2005).

On the basis of $16 \mathrm{~S}$ rRNA gene sequence similarity, strains FWC $21^{\mathrm{T}}$ and LMG $11050^{\mathrm{T}}$ were most closely related not to species of the genus Caulobacter but to Phenylobacterium koreense $(96.95 \%)$ and to Phenylobacterium immobile $(96.31 \%)$. Strain FWC $38^{\mathrm{T}}$ was most closely related to Caulobacter fusiformis and Caulobacter henricii (both $96.80 \%)$. The $16 \mathrm{~S}$ rRNA gene sequence of strain FWC $21^{\mathrm{T}}$ showed $95.69 \%$ similarity to that of C. fusiformis ATCC $15257^{\mathrm{T}}, 96.53 \%$ to $C$. henricii ATCC $15253^{\mathrm{T}}$, $95.83 \%$ to $C$. vibrioides VKM B-1496 ${ }^{\mathrm{T}}$ and $96.66 \%$ to FWC $38^{\mathrm{T}}$. The similarity between strains FWC $21^{\mathrm{T}}$ and LMG $11050^{\mathrm{T}}$ was $98.19 \%$, but the two strains could easily be distinguised by their distinct morphology (Figs 1 and 2).

Because the species of the genera Caulobacter and Phenylobacterium are phylogenetically rather closely related, a search for nucleotides in the 16S rRNA gene sequences that might be useful to discern the genera of the order Caulobacterales was conducted. In this search, all type species of the genera Caulobacter, Phenylobacterium, Brevundimonas and Asticcacaulis were included. Nucleotides characteristic for one genus were checked against other strains clustering within the order 

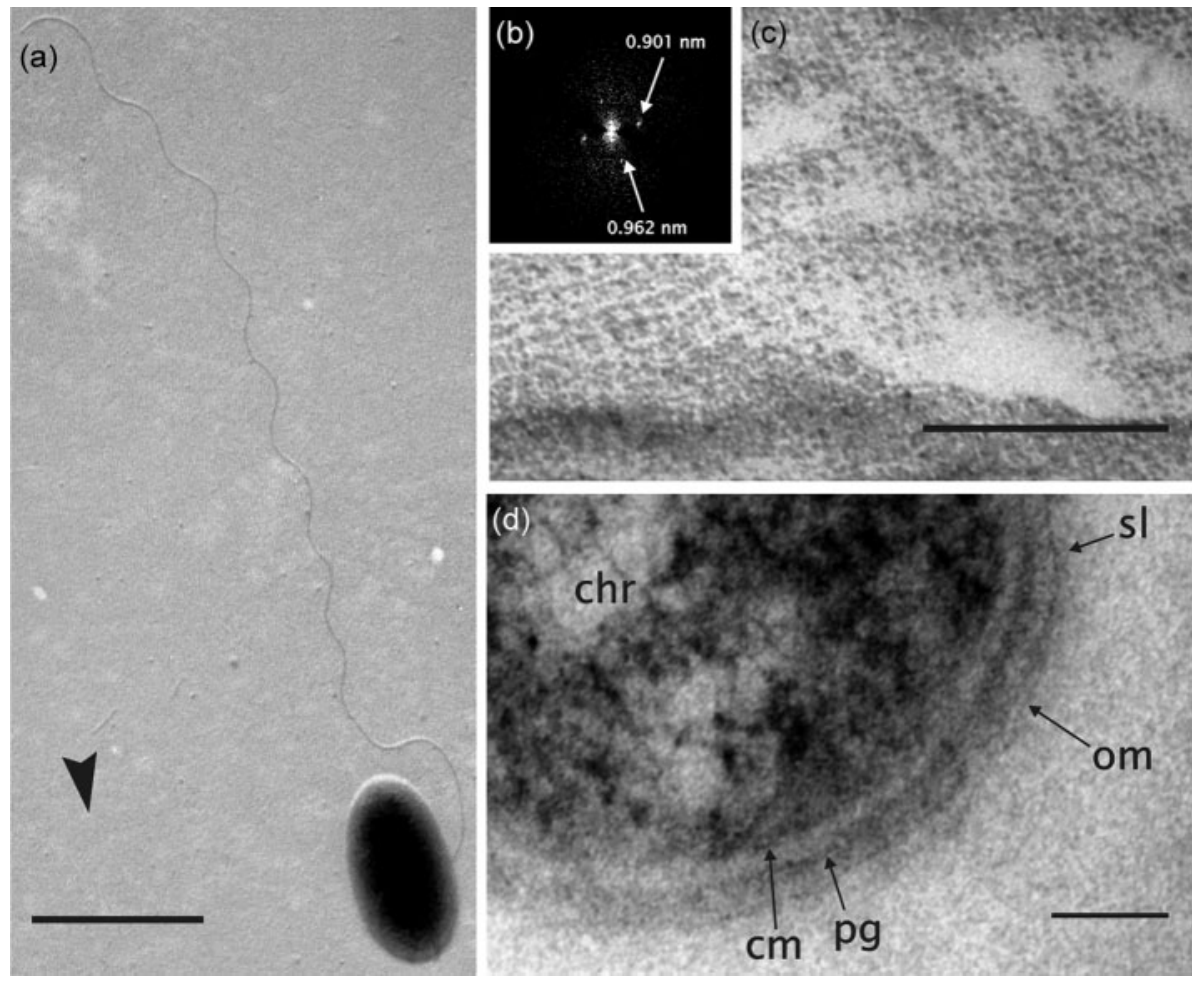

Fig. 2. Ultrastructure of cells of strain LMG $11050^{\top}$. (a) Individual, monopolar, monotrichously flagellated cell. Arrowhead indicates direction of shadow-casting. (b) Fast-Fourier Transform (FFT) of part of the surface layer, shown in (c), with ordered details down to 0.90 and $0.96 \mathrm{~nm}$. (c) Shadow-cast bacterial surface, showing the presence of an S-layer. (d) Detailed view of the cell wall $(90 \mathrm{~nm}$ ultrathin section), presenting the Gram-negative wall architecture. cm, Cytoplasmic membrane, pg, peptidoglycan; om, outer membrane; sl, surface layer; chr, bacterial chromosome. Bars, $1 \mu \mathrm{m}(\mathrm{a}), 100 \mathrm{~nm}$ (c) and $50 \mathrm{~nm}$ (d).

Caulobacterales for consistency. The search revealed a number of nucleotides which could be used to identify strains within this order unambiguously (Table 1). All species were missing nucleotides 71-88, 183-190, 206-211 and 452-476 (Escherichia coli numbering). Nucleotides 1258-1278 which form loop 46 in V8 (Neefs et al., 1993) were missing in the genera Brevundimonas and Asticcacaulis, but were present in the genera Caulobacter and Phenylobacterium. In this region, the genus Phenylobacterium had 1265-T and 1270-A while the genus Caulobacter had either $1265-\mathrm{C}$ or $-\mathrm{A}$ and $1270-\mathrm{G}$ or $-\mathrm{T}$ at these positions. All species of the genus Phenylobacterium had 122-G, while the other three genera in the order Caulobacterales had 122-A. Furthermore, species of the genus Phenylobacterium had 178-T, which was either G or $A$ in the genera Caulobacter, Brevundimonas and Asticcacaulis. These three genera had 359-G but this was -A in all species of the genus Phenylobacterium. A marker nucleotide for the genus Asticcacaulis was 639-A, which was 639-G for all other members of the order Caulobacterales. Species of the genus Brevundimonas had 610-T, which was $610-G$ for the three other genera. Species of the genera Brevundimonas and Asticcacaulis had 823-A and 877-A, which were $823-\mathrm{G}$ and $877-\mathrm{C}$ for the genera Caulobacter and Phenylobacterium. Most species of the genus
Caulobacter had 1216-A, the only exception being strain FWC $38^{\mathrm{T}}$, which had $1216-\mathrm{G}$, similar to all species of the genera Phenylobacterium, Brevundimonas and Asticcacaulis.

The cellular fatty acid contents of the type strains of the genera Caulobacter, Brevundimonas and Phenylobacterium were determined by MIDI and are shown in Supplementary Table S1 (see IJSEM Online). Strain FWC $21^{\mathrm{T}}$ possessed only trace amounts of $\mathrm{C}_{14: 0}$ but considerable amounts of $\mathrm{C}_{12: 1} 3$ $\mathrm{OH}$. It was the only strain in this study found to contain iso$\mathrm{C}_{17: 0}$, although only in trace amounts, and the unidentified fatty acid ECL 17.897. Strain LMG $11050^{\mathrm{T}}$ also contained only trace amounts of $\mathrm{C}_{14: 0}$ and $\mathrm{C}_{17: 1} \omega 8 c$, but high amounts of summed feature 7 (see Supplementary Table S1). Strain FWC $38^{\mathrm{T}}$ was exceptional in the large amounts of trans-11-methyl-12-octadecenoic acid (ECL 18.080) present, while the amounts of summed feature 7 (see Supplementary Table S1 in IJSEM Online) were considerably reduced. The trans-configuration of 11-methyl-12-octadecenoic acid was confirmed by ${ }^{1} \mathrm{H}$-NMR spectroscopy in accordance to Albuquerque et al. (2002). $\mathrm{C}_{18: 0}$, a fatty acid found previously only in $C$. henricii, but lacking in all other Caulobacter strains (Abraham et al., 1999), was detected in amounts below $1 \%$. Strains FWC $21^{\mathrm{T}}$, FWC $38^{\mathrm{T}}$ and LMG $11050^{\mathrm{T}}$ did not contain ECL 11.798 . 


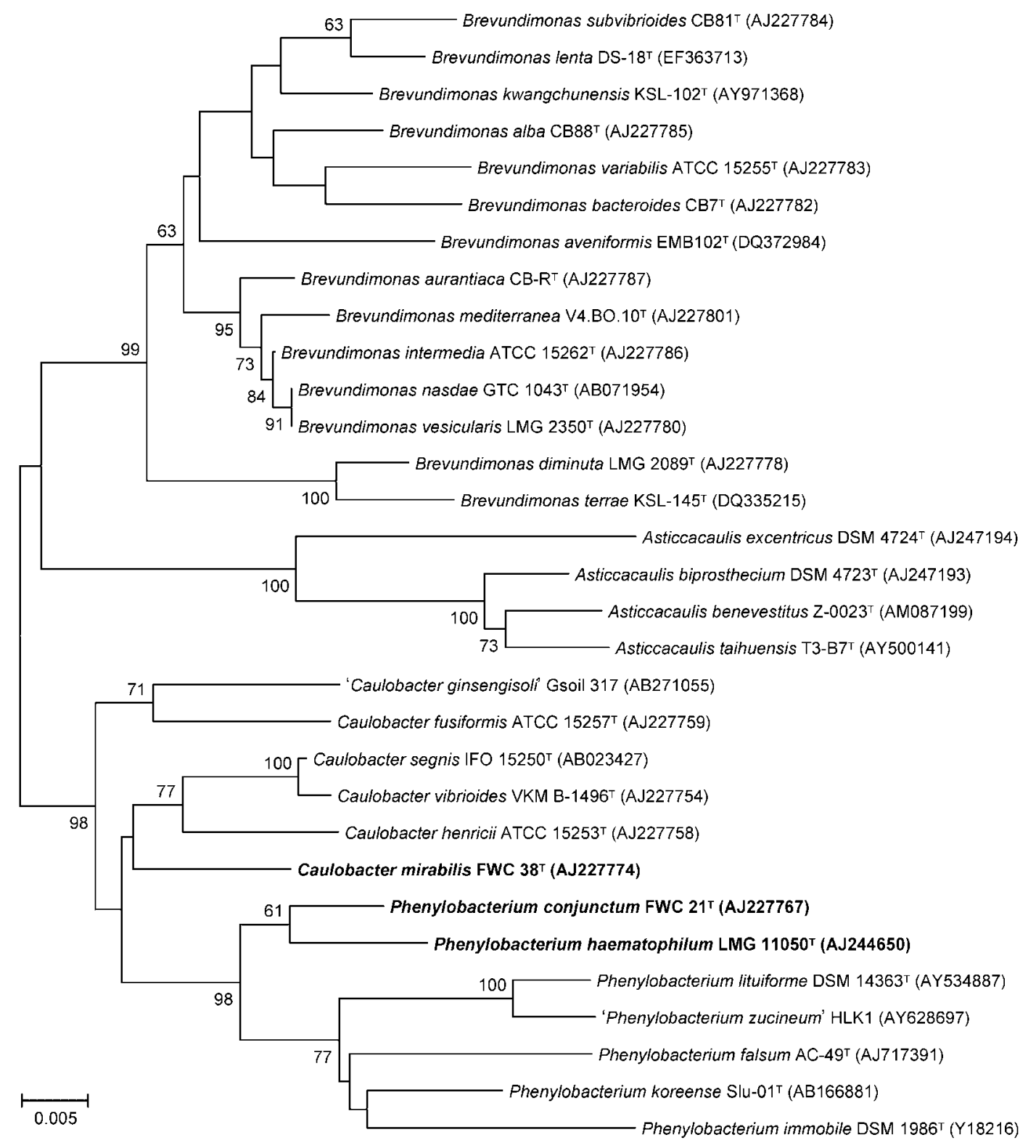

Fig. 3. Unrooted dendrogram using neighbour-joining based on the $16 \mathrm{~S}$ rRNA gene sequences of strains $\mathrm{FWC} 38^{\top}, \mathrm{FWC} 21^{\top}$ and LMG $11050^{\top}$ and the type strains of the genera Caulobacter, Phenylobacterium and Brevundimonas. Caulobacter crescentus $\mathrm{CB}^{\top}$ is conspecific with C. vibrioides VKM $1496^{\top}$ (Abraham et al., 1999) and not shown here. Bar, 5 nucleotide substitutions per 1000 bases.

Strains of the genus Caulobacter were found to contain significant amounts of the fatty acids $\mathrm{C}_{12: 1} 3-\mathrm{OH}, \mathrm{C}_{14: 0}$, $\mathrm{C}_{16: 0}$, summed feature 7 and ECL 18.080. All strains, except Caulobacter segnis, also contained $\mathrm{C}_{15: 0}, \mathrm{C}_{17: 0}$, $\mathrm{C}_{17: 1} \omega 6 c$ and $\mathrm{C}_{17: 1} \omega 8 c$. Strains of the genus Brevundimonas could be differentiated from strains of the genus Caulobacter by the absence of ECL 11.789 and by the presence of at least trace amounts of ECL 17.897, only trace amounts of $\mathrm{C}_{12: 1} 3-\mathrm{OH}$, higher amounts of $\mathrm{C}_{12: 0} 3-\mathrm{OH}$ and by a higher content of the dominant fatty acid, summed feature 7 (Abraham et al., 1999). Species of the genus Phenylobacterium differed from those of the genus Caulobacter by the lack of ECL 11.798, the presence of only trace amouns of $\mathrm{C}_{14: 0}$ and a higher amount of $\mathrm{C}_{12: 0} 3-\mathrm{OH}$ and from the genus Brevundimonas by the presence of $\mathrm{C}_{12: 1} 3-\mathrm{OH}$ [most probably $\mathrm{C}_{12: 1} \omega 6$ according to Bellmann \& Lingens (1985)], the occurrence of only trace amounts of $\mathrm{C}_{14: 0}$ and the presence of $\mathrm{C}_{12: 0}$. Strains FWC $21^{\mathrm{T}}$, FWC $38^{\mathrm{T}}$ and LMG $11050^{\mathrm{T}}$ shared a lack of ECL 11.798 with species of the genus Brevundimonas. These strains shared the presence of considerable amounts of $\mathrm{C}_{12: 1} 3-\mathrm{OH}$ with species of the genus Caulobacter and the 
Table 1. Marker nucleotides in the 16S rRNA genes of members of the order Caulobacterales

All species are lacking nucleotides 71-88, 183-190, 206-211, 452-476 (E. coli numbering). Nucleotides 1258-1278 are missing in the genera Brevundimonas and Asticcacaulis but are present in species of the genera Caulobacter and Phenylobacterium.

\begin{tabular}{|c|c|c|c|c|}
\hline E. coli no. & Phenylobacterium & Caulobacter & Brevundimonas & Asticcacaulis \\
\hline 122 & G & A & A & A \\
\hline 178 & $\mathrm{~T}$ (falsum: $\mathrm{C})$ & $\mathrm{G}, \mathrm{A}$ & $\mathrm{G}, \mathrm{A}$ & G, A \\
\hline 359 & $\mathrm{~A}$ & G & G & G \\
\hline 610 & G & G & $\mathrm{T}$ & G \\
\hline 639 & G & G & G & A \\
\hline 823 & G & G & A & A \\
\hline 877 & $\mathrm{C}$ & $\mathrm{C}$ & A & A \\
\hline 1145 & $\mathrm{C}$ & $\mathrm{C}$ & A & A \\
\hline 1265 & $\mathrm{~T}$ (falsum: A) & $\mathrm{C}, \mathrm{A}$ & Missing & Missing \\
\hline 1270 & A (falsum: $\mathrm{T})$ & $\mathrm{G}, \mathrm{T}$ & Missing & Missing \\
\hline
\end{tabular}

fatty acids of summed feature 7 were not as dominant as they were in Brevundimonas species. The unusually high amount of trans-11-methyl-12-octadecenoic acid in strain FWC $38^{\mathrm{T}}$ resulted in a very distinctive lipid pattern as seen in the negative fast atom bombardment mass spectra of the polar lipids (see Supplementary Fig. S2 in IJSEM Online). The [M$\mathrm{H}]^{-}$ions at $m / z 1410$ or 1412 characteristic for strains of the genera Caulobacter or Brevundimonas were both absent and a very strong signal was observed for $m / z 1438$.

Lipids were extracted using a modified Bligh-Dyer procedure (Bligh \& Dyer, 1959) as described previously (Vancanneyt et al., 1996). The lipids were fractionated by sequential elution with dichloromethane, acetone and methanol, which resulted in three fractions of different polarity: neutral-, glyco- and phospholipids. The eluates were collected and dried under nitrogen. The phospholipid fractions were analysed by fast atom bombardment mass spectrometry (FAB-MS). FAB-MS in the negative mode was performed on the first of two mass spectrometers of a tandem high-resolution instrument in a $\mathrm{E}_{1} \mathrm{~B}_{1} \mathrm{E}_{2} \mathrm{~B}_{2}$ configuration (JMS-HX/HX110A, JEOL) at $10 \mathrm{kV}$ accelerating voltage with the resolution set to $1: 1000$. The JEOL FAB gun was operated at $6 \mathrm{kV}$ with xenon. A mixture of triethanolamine and tetramethylurea (Japanese matrix) was used as the matrix in the negative mode. Negative daughter ion spectra were recorded using all four sectors of the tandem mass spectrometer. High energy collisioninduced dissociation (CID) took place in the third field free region. Helium served as the collision gas at a pressure sufficient to reduce the precursor ion signal to $30 \%$ of the original value. The collision cell was operated at ground potential in the negative mode. The resolution of MS2 was set to $1: 1000$. FAB-CID spectra (linked scans of MS2 at constant $\mathrm{B} / \mathrm{E}$ ratio) were recorded with $300 \mathrm{~Hz}$ filtering on a JEOL DA 7000 data system.

The polar lipids found in the novel strains examined in this study, together with those of the type strains of Caulobacter species, Phenylobacterium immobile DSM 1986 ${ }^{\mathrm{T}}$, Phenylobacterium falsum LMG $22693^{\mathrm{T}}$ and Phenylo- bacterium lituiforme DSM $14363^{\mathrm{T}}$ are given in Supplementary Table S2 (see IJSEM Online). All strains had phosphatidylglycerol (PG) and 3-O-[6'-(sn-glycero3 "-phosphoryl)- $\alpha$-D-glucopyranosyl]-sn-glycerol (PGL) (Abraham et al., 1997). The main PG for all of the strains was the 1-octadecenoyl-2-hexadecanoyl compound. Compared with strain FWC $38^{\mathrm{T}}$, strains FWC $21^{\mathrm{T}}$ and LMG $11050^{\mathrm{T}}$ had a larger variety of PG. The PGLs of these strains were not uniform. While strain FWC $21^{\mathrm{T}}$ and LMG $11050^{\mathrm{T}}$ possessed either PGLs of molecular mass 1411 or 1413, these lipids were completely absent in strain FWC $38^{\mathrm{T}}$. Instead, the major PGL was found at a molecular mass of 1439 due to the high content of trans-11-methyl-12octadecenoic acid (11-methyl- $\mathrm{C}_{18: 1} \omega 5 t$, ECL 18.080). Only in strains LMG $11050^{\mathrm{T}}$ and P. falsum LMG $22693^{\mathrm{T}}$ could a sulfolipid belonging to the sulfoquinovosyl diacylglycerol type be detected (see Supplementary Table S2 in IJSEM Online). The analyses of the polar lipids of Phenylobacterium immobile DSM $1986^{\mathrm{T}}$ and Phenylobacterium lituiforme DSM $14363^{\mathrm{T}}$ led to the identification of 12 different PGs and 36 different PGLs, the majority of them described here for the first time (see Supplementary Table S3 in IJSEM Online). Only six of these 48 lipids were found in both species, underlining the fact that these are important biomarkers for the species. It was interesting to compare the PGLs of these two species of the genus Phenylobacterium with those identified in species of the genera Caulobacter and Brevundimonas. While all of the PGLs analysed from Caulobacter and Brevundimonas species so far have had $\mathrm{C}_{18: 1}$ at the $s n$-1-position of the phosphatidyl moiety, this fatty acid is not always conserved in Phenylobacterium species and saturated fatty acids are also found at this position. Furthermore, species of the genera Brevundimonas and Caulobacter have either $\mathrm{C}_{18: 1}$ or $\mathrm{C}_{19: 1}$ at the $s n-2^{\prime}$-position in the glycosyl moiety but this again is not conserved in members of the genus Phenylobacterium. PGLs with molecular masses $<1400$ have so far only been observed in P. immobile DSM $1986^{\mathrm{T}}$.

To determine the salt tolerances of the novel isolates, strains were grown in $20 \mathrm{ml}$ PYEM medium amended with 
$0,5,10,20,30,40,60,80$ or $100 \mathrm{~g} \mathrm{l}^{-1} \mathrm{NaCl}$. The optical density of the cell suspension was determined at the beginning of the experiment and again after 2 days. The differences between these two measurements were used to determine salt tolerances. Substrate specificities were determined with the API Biotype 100 gallery (bioMérieux) and from Biolog GN substrate utilization tests (Rüger \& Krambeck, 1994). Enzyme activities were assessed by API ZYM tests (bioMérieux) according to manufacturer's recommendations (see Supplementary Table S4). Strains FWC $21^{\mathrm{T}}$, FWC $38^{\mathrm{T}}$ and LMG $11050^{\mathrm{T}}$ could all grow without $\mathrm{NaCl}$, but at a slightly reduced rate. They could also all grow at a concentration of $10 \mathrm{~g} \mathrm{l}^{-1}$ $\mathrm{NaCl}$. Strain FWC $21^{\mathrm{T}}$ showed good growth with $30 \mathrm{~g} \mathrm{l}^{-1}$ $\mathrm{NaCl}$ and could even grow with $40 \mathrm{~g} \mathrm{l}^{-1} \mathrm{NaCl}$, although only slowly. Strain FWC $38^{\mathrm{T}}$ showed a similar salt tolerance, but growth with $40 \mathrm{gl}^{-1} \mathrm{NaCl}$ was somewhat better than that of strain FWC $21^{\mathrm{T}}$. In contrast to these strains, strain LMG $11050^{\mathrm{T}}$ could not grow in the presence of $20 \mathrm{~g} \mathrm{l}^{-1} \mathrm{NaCl}$.

Species of the genus Caulobacter show a characteristically small window of salt tolerances. They grow best with $5 \mathrm{~g} \mathrm{l}^{-1} \mathrm{NaCl}$ and they do not tolerate concentrations of $20 \mathrm{~g} \mathrm{l}^{-1}$. In contrast, species of the genus Brevundimonas species grow best at concentrations of $0-30 \mathrm{~g} \mathrm{l}^{-1} \mathrm{NaCl}$ and the upper limit of salt tolerance during growth varies widely between the different species. Strains FWC $21^{\mathrm{T}}$, FWC $38^{\mathrm{T}}$ and LMG $11050^{\mathrm{T}}$ all showed reduced growth without salt and at salt concentrations above $20 \mathrm{~g} \mathrm{l}^{-1}$, a characteristic similar to that found for species of the genus Caulobacter. Strain LMG $11050^{\mathrm{T}}$ could not tolerate $20 \mathrm{~g} \mathrm{l}^{-1}$ salt, but strains FWC $21^{\mathrm{T}}$ and FWC $38^{\mathrm{T}}$ could grow slowly with $40 \mathrm{~g} \mathrm{l}^{-1} \mathrm{NaCl}$. Such a high salt tolerance has not been observed previously in the genus Caulobacter.

All of the novel strains could grow between 20 and $40{ }^{\circ} \mathrm{C}$. The optimal growth temperatures were $30{ }^{\circ} \mathrm{C}$ for strain FWC $21^{\mathrm{T}}, 40{ }^{\circ} \mathrm{C}$ for LMG $11050^{\mathrm{T}}$ and $20-30{ }^{\circ} \mathrm{C}$ for strain FWC $38^{\mathrm{T}}$. While strains LMG $11050^{\mathrm{T}}$ and FWC $38^{\mathrm{T}}$ showed slow growth at $10{ }^{\circ} \mathrm{C}$, no growth was seen for strain FWC $21^{\mathrm{T}}$.

As the species of the genus Phenylobacterium were more closely related to the genus Caulobacter than to the genus Brevundimonas, we attempted to use antibodies SMT2, specific for the genus Caulobacter, and SMT7, specific for the genus Brevundimonas, using the Westprinting technique (Abraham et al., 1999). In our hands, these antibodies were not specific enough to differentiate species of the genus Phenylobacterium from those of the genera Caulobacter or Brevundimonas, although a slightly better reaction was observed for SMT2.

\section{Conclusions}

Due to the heterogeneity of the novel isolates, three different taxa could be discerned and a novel species of the genus Caulobacter and two novel species of the genus Phenylobacterium are proposed. The discriminating characteristics of the newly proposed species and their nearest neighbours are summarized in Table 2 and Supplementary Table S5 (see IJSEM Online).

The inclusion of a prosthecate species into the genus Phenylobacterium requires an emendation of the genus description given by Lingens et al. (1985) and subsequently emended by Kanso \& Patel (2004), Tiago et al. (2005) and Zhang et al. (2007).

\section{Emendation of the genus Phenylobacterium (Lingens et al. 1985, emend. Kanso and Patel 2004, emend. Tiago et al. 2005, emend. Zhang et al. 2007)}

Cells stain Gram-negative, are non-spore-forming straight to slightly curved rods, coccobacilli or cocci measuring $0.7-$ $1.0 \times 1.0-2.0 \mu \mathrm{m}$ and occur singly, in pairs or short chains. Cells of some species have prosthecae. Cells may form rosettes. Filamentous cells tend to form in old cultures. Species may be strict aerobes or facultative anaerobes and may be motile or non-motile. Cells do not form sheaths and are not acid-fast. Species are lipase $\left(\mathrm{C}_{14}\right), \alpha-$ galactosidase, $\alpha$-mannosidase, $\beta$-glucosidase and $\alpha$-fucosidase-negative. Based on the $16 \mathrm{~S}$ rRNA gene sequence analysis, members of this genus form a monophyletic group within the order Caulobacterales, class Alphaproteobacteria. All species of the genus Phenylobacterium have 122-G in their 16S rRNA gene sequences while the other genera of the order Caulobacterales genera have 122-A. Furthermore, species of the genus Phenylobacterium have a $178-\mathrm{T}$ which is either 178-G or 178-A in the genera Caulobacter, Brevundimonas and Asticcacaulis. These three genera have a 359-G which is 359-A in all species of the genus Phenylobacterium. Main cellular fatty acids are $\mathrm{C}_{16: 0}$ and $\mathrm{C}_{18: 1} \omega 7$. In contrast with species of the genera Brevundimonas and Caulobacter, $\mathrm{C}_{14: 0}$ is present only in traces. Hydroxy fatty acids are $\mathrm{C}_{12: 0} 3$ $\mathrm{OH}$ and $\mathrm{C}_{12: 1}$ 3-OH. All species of the genus Phenylobacterium have the phospholipids phosphatidylglycerol and 3-O-[6'-(sn-glycero- $3^{\prime \prime}$-phosphoryl $)-\alpha$-D-glucopyranosyl]-sn-glycerols. Some species also possess the sulfolipids sulfoquinovosyl diacylglycerols. The DNA G+C ratio is between 66.5 and $68.5 \mathrm{~mol} \%$. Isolated from soil, water and blood. The type species is Phenylobacterium immobile Lingens et al. 1985.

\section{Description of Phenylobacterium conjunctum sp. nov.}

Phenylobacterium conjunctum (con.junc'tum. L. neut. adj. conjunctum adjacent, the Phenylobacterium species which is closely related to the genus Caulobacter).

The description of Phenylobacterium conjunctum is the same as that given for the genus (Lingens et al., 1985) and emended by Kanso \& Patel (2004) and in this study, with the following additional characteristics. Prosthecate bacteria, colony colour is tan, cells are bacteroid. Cells are 
Table 2. Discriminating characteristics of species of the genera Caulobacter and Phenylobacterium

Taxa, 1, strain FWC $38^{\mathrm{T}}$; 2, C. vibrioides; 3, C. henricii; 4, C. segnis (data from Urakami et al., 1990); 5, strain FWC 21 ${ }^{\mathrm{T}}$; 6, P. immobile DSM 1986 ${ }^{\mathrm{T}}$ (Aslam et al., 2005); 7, P. lituiforme DSM $14363^{\mathrm{T}}$ (Aslam et al., 2005); 8, P. koreense Slu-01 ${ }^{\mathrm{T}}$ (Aslam et al., 2005); 9, P. falsum AC-49 ${ }^{\mathrm{T}}$ (Tiago et al., 2005); 10, 'Phenylobacterium zucineum' (Zhang et al., 2007); 11, strain LMG 11050 (Segers et al., 1994). +, Positive; (+), weakly positive; -, negative; ND, not determined.

\begin{tabular}{|c|c|c|c|c|c|c|c|c|c|c|c|}
\hline Characteristic & 1 & 2 & 3 & 4 & 5 & 6 & 7 & 8 & 9 & 10 & 11 \\
\hline DNA G + C (mol\%) & 68.0 & ND & $\mathrm{ND}$ & $67-68$ & 67.0 & 67.8 & $66.5^{\star}$ & 68.1 & 66.9 & 71.2 & 67.8 \\
\hline Prostheca & + & + & + & - & + & - & - & - & - & - & - \\
\hline Colour & Yellow & Colourless & Yellow & Colourless & Tan & Colourless & Yellow & Colourless & White & Grey & Whitish \\
\hline $\mathrm{NaCl}$ tolerance $\left(\mathrm{g} \mathrm{l}^{-1}\right)$ & 40 & $<10$ & 10 & $\mathrm{ND}$ & $<20$ & $<10^{*}$ & $<10$ & 20 & 70 & $<60$ & 10 \\
\hline Oxidase & + & ND & $\mathrm{ND}$ & + & + & - & - & + & + & + & + \\
\hline Nitrate reduction & - & ND & ND & - & - & $-*$ & $+^{*}$ & + & - & + & - \\
\hline $\mathrm{N}_{2}$ from $\mathrm{NO}_{3}^{-}$ & - & $\mathrm{ND}$ & $\mathrm{ND}$ & - & - & - & + & - & - & $\mathrm{ND}$ & - \\
\hline \multicolumn{12}{|l|}{ Utilization of: } \\
\hline Acetate & - & - & - & - & - & - & + & + & $\mathrm{ND}$ & - & - \\
\hline Citrate & - & - & - & - & + & $-^{*}$ & + & - & - & - & + \\
\hline Fumarate & - & - & - & - & ND & $(+)$ & + & - & ND & ND & ND \\
\hline Glucose & + & - & - & - & + & $-*$ & + & - & - & + & + \\
\hline Glycerol & - & - & - & - & - & - & + & - & - & ND & - \\
\hline Phenylalanine & + & - & - & - & - & $+^{*}$ & $+^{*}$ & + & - & + & - \\
\hline Succinate & + & - & - & - & - & $(+)^{*}$ & + & - & + & $\mathrm{ND}$ & - \\
\hline Sucrose & - & - & - & - & - & $-*$ & $+^{*}$ & - & - & - & - \\
\hline Xylose & - & - & - & - & $\mathrm{ND}$ & $-*$ & $+^{*}$ & - & - & $\mathrm{ND}$ & - \\
\hline Malonate & - & - & - & - & + & - & - & - & $\mathrm{ND}$ & - & - \\
\hline$\alpha$-L-Rhamnose & + & - & - & - & - & - & - & - & - & - & - \\
\hline $\mathrm{N}$-Acetylglucosamine & + & - & - & - & - & - & - & - & ND & - & - \\
\hline DL-Lactate & + & - & - & - & - & - & - & - & ND & - & - \\
\hline$\beta$-Hydroxybutyrate & + & - & - & - & - & - & - & + & - & + & - \\
\hline L-Aspartate & + & - & - & - & - & - & - & ND & - & $\mathrm{ND}$ & - \\
\hline L-Glutamate & + & - & - & - & - & - & - & ND & + & $\mathrm{ND}$ & - \\
\hline L-Proline & + & - & - & - & - & - & - & + & + & + & - \\
\hline L-Alanine & $(+)$ & - & - & - & - & - & - & - & + & - & - \\
\hline
\end{tabular}

${ }^{\star}$ Data taken from Tiago et al. (2005).

$1.15-1.60 \mu \mathrm{m}$ in length and $0.5-0.7 \mu \mathrm{m}$ in width. The cell wall is of Gram-negative architecture and is about $25 \mathrm{~nm}$ in width, layered with an S-layer of $7.4 \mathrm{~nm}$ thickness. Two major fatty acids are summed feature 7 (see Supplementary Table S1) and $\mathrm{C}_{16: 0}$. The minor fatty acids are summed feature 4 (see Supplementary Table S1) and $\mathrm{C}_{15: 0}$. Can grow on peptone-yeast extract media with $0-10 \mathrm{~g} \mathrm{l}^{-1}$ $\mathrm{NaCl}$, with optimal growth at around $5 \mathrm{~g} \mathrm{l}^{-1} \mathrm{NaCl}$. Tests are positive for the activities of acid and alkaline phosphatase, esterase $\left(\mathrm{C}_{4}\right)$, leucine arylamidase, naphtholAS-BI-phosphohydrolase and weak activities are detected for cystine arylamidase, esterase lipase $\left(\mathrm{C}_{8}\right)$, trypsin, $N$ acetyl- $\beta$-glucosaminidase, $\alpha$-glucosidase and $\alpha$-chymotrypsin. No activity for $\alpha$-fucosidase, $\alpha$ - or $\beta$-galactosidase, $\alpha$-glucuronidase, $\beta$-glucosidase, $\alpha$-mannosidase or valine arylamidase. Able to utilize arabinose, citrate, dextrin, glucose, malonate, maltose, mannose and Tween 40 , but not acetate, $N$-acetyl-D-glucosamine, cis-aconitic acid, adonitol, alaninamide, L- and D-alanine, L-alanylglycine, 2-amino ethanol, $\gamma$-aminobutyric acid, D-arabitol,
L-asparagine, L-aspartic acid, bromosuccinic acid, 2,3butanediol, DL-carnitine, cellobiose, $\alpha$-cyclodextrin, ierythritol, formate, D-fructose, L-fucose, D-galactose, D-galactonic acid lactone, D-galacturonic acid, gentiobiose, D-gluconic acid, D-glucosaminic acid, glucose 1- and glucose 6-phosphate, glucuronamide, D-glucuronic acid, L-glutamic acid, glycerol, DL- $\alpha$-glycerol phosphate, glycogen, glycyl-L-glutamic acid, L-histidine, $\alpha-, \beta$ - and $\gamma$ hydroxybutyric acids, $p$-hydroxyphenylacetic acid, hydroxy L-proline, inosine, myo-inositol, itaconic acid, $\alpha$-ketobutyrate, $\alpha$-ketoglutarate, $\alpha$-ketovaleric acid, DL-lactate, $\alpha$-Dlactose, lactulose, L-leucine, D-mannitol, melibiose, methyl $\beta$-D-glucoside, glycyl L-aspartic acid, methyl pyruvate, monomethyl succinate, L-ornithine, L-phenylalanine, phenylethylamine, L-proline, propionate, psicose, putrescine, L-pyroglutamic acid, quinic acid, raffinose, Lrhamnose, D-saccharic acid, sebacic acid, D- and L-serine, D-sorbitol, succinamic acid, succinic acid, sucrose, Tween 80, trehalose, L-threonine, turanose, thymidine, uridine, urocanic acid or xylitol. Does not grow with salt 
concentrations above $20 \mathrm{~g} \mathrm{l}^{-1} \mathrm{NaCl}$. Growth is observed between 20 and $40{ }^{\circ} \mathrm{C}$, with optimal growth at around $30{ }^{\circ} \mathrm{C}$. The DNA G $+\mathrm{C}$ content is $67.0 \mathrm{~mol} \%$.

The type strain, FWC $21^{\mathrm{T}}\left(=\right.$ LMG $24262^{\mathrm{T}}=$ CCUG $\left.55074^{\mathrm{T}}\right)$, was isolated from a bench-scale rotating biological contactor at the University of British Columbia, Canada.

\section{Description of Phenylobacterium haematophilum sp. nov.}

Phenylobacterium haematophilum (hae.ma.to.phi'lum. Gr. n. haema -atos blood; Gr. adj. philos loving; N.L. neut. adj. haematophilum blood-loving).

The description of Phenylobacterium haematophilum is the same as that given for the genus (Lingens et al., 1985) and emended by Kanso \& Patel (2004) and in this study, with the following additional characteristics. The polar lipid fraction contains phosphatidylglycerols, sulfoquinovosyl diacylglycerol of $834 \mathrm{amu}$ and 6-phosphatidyl- $\alpha$-D-glucopyranosyl diacylglycerol of $1413 \mathrm{amu}$ or higher. Major fatty acids are $\mathrm{C}_{18: 1} \omega 7$ and $\mathrm{C}_{16: 0}$ (see Supplementary Table S1), minor fatty acids are summed feature $4, \mathrm{C}_{15: 0}$ and trans11-methyl-12-octadecenoic acid. The main hydroxyl fatty acid is $\mathrm{C}_{12: 0} 3-\mathrm{OH}$ (see Supplementary Table S1). Is able to grow on peptone-yeast extract media with $0-10 \mathrm{~g} \mathrm{l}^{-1} \mathrm{NaCl}$ with optimal growth at around $5 \mathrm{~g} \mathrm{l}^{-1} \mathrm{NaCl}$. Does not tolerate salt concentrations above $20 \mathrm{~g} \mathrm{l}^{-1} \mathrm{NaCl}$. Growth is observed between 10 and $40{ }^{\circ} \mathrm{C}$, with optimal growth around $37{ }^{\circ} \mathrm{C}$. Positive in results for activities of acid and alkaline phosphatase, esterase $\left(\mathrm{C}_{4}\right)$, leucine arylamidase, naphthol-AS-BI-phosphohydrolase and for weak activities of cystine arylamidase, esterase lipase $\left(\mathrm{C}_{8}\right)$, trypsin, $N$ acetyl- $\beta$-glucosaminidase, $\alpha$-glucosidase and $\alpha$-chymotryp$\sin$. No activity is detected for $\alpha$-fucosidase, $\alpha$ - and $\beta$ galactosidase, $\alpha$-glucuronidase, $\beta$-glucosidase, $\alpha$-mannosidase and valine arylamidase. Is able to utilize arabinose, citrate, $\beta$-hydroxybutyric acid, $\alpha$-D-glucose, L-glutamic acid, glycyl-L-glutamic acid, itaconic acid, maltose, mannose, methyl $\beta$-D-glucoside, methyl pyruvate, L-proline, propionate, sebacic acid and Tweens 40 and 80 . Does not utilize acetate, $\mathrm{N}$-acetyl-D-glucosamine, cis-aconitic acid, adonitol, alaninamide, $\mathrm{L}$ - and $\mathrm{D}$-alanine, $\mathrm{L}$-alanylglycine, $\gamma$ aminobutyric acid, 2-aminoethanol, D-arabitol, L-asparagine, L-aspartic acid, bromosuccinic acid, 2,3-butanediol, DL-carnitine, cellobiose, $\alpha$-cyclodextrin, dextrin, i-erythritol, formate, D-fructose, L-fucose, D-galactonic acid lactone, D-galactose, D-galacturonic acid, gentiobiose, D-gluconic acid, D-glucosaminic acid, glucose 1- and 6-phosphate, glucuronamide, D-glucuronic acid, glycerol, DL- $\alpha$-glycerolphosphate, glycogen, glycyl-L-aspartic acid, L-histidine, $\alpha$ hydroxybutyric acid, $\gamma$-hydroxybutyric acid, $p$-hydroxyphenylacetic acid, hydroxy L-proline, inosine, myo-inositol, $\alpha$-ketobutyric acid, $\alpha$-ketoglutaric acid, $\alpha$-ketovaleric acid, DL-lactate, $\alpha$-lactose, L-leucine, malonate, D-mannitol, melibiose, monomethylsuccinate, L-ornithine, L-phenylalanine, phenylethylamine, psicose, putrescine, L-pyroglutamic acid, quinic acid, raffinose, L-rhamnose, D-saccharic acid, D- and L-serine, D-sorbitol, succinamic acid, succinate, sucrose, L-threonine, thymidine, trehalose, turanose, uridine, urocanic acid and xylitol. The species can use adonitol but not $(+)$-L-arabinose, caprate, $\beta-(+)$-Dfructose, $(+)$-D-galactose, $\alpha-(+)$-D-glucose, glycerol, Lhistidine, myo-inositol, $\alpha$-lactose, maltose, D-mannitol, $(+)$-D-mannose, D-sorbitol, sucrose, $(+)$-D-trehalose or (+)-D-xylose. The $\mathrm{G}+\mathrm{C}$ content is $67.8 \mathrm{~mol} \%$.

The type strain, LMG $11050^{\mathrm{T}}$ (=CCUG $26751^{\mathrm{T}}$ ), was isolated from human blood (Göteborg, Sweden).

\section{Description of Caulobacter mirabilis sp. nov.}

Caulobacter mirabilis (mi.ra'bi.lis. L. masc. adj. mirabilis strange, the strange Caulobacter which is unique in its high content of trans-11-methyl-12-octadecenoic acid).

The description of Caulobacter mirabilis is the same as that given for the genus (Henrici \& Johnson, 1935, emended by Poindexter, 1964; Abraham et al., 1999), with the following additional characteristics. Prosthecate bacteria, colony colour is bright yellow, cells are bacteroid. The two major fatty acids are trans-11-methyl-12-octadecenoic acid and $\mathrm{C}_{16: 0}$. Minor fatty acids are summed feature 7 (see Supplementary Table S1), $\mathrm{C}_{15: 0}, \mathrm{C}_{17: 0}$, and $\mathrm{C}_{20: 0}$. The 6phosphatidyl- $\alpha$-D-glucopyranosyl diacylglycerol fraction does not contain the compounds of $1409 \mathrm{amu}$, characteristic for the Caulobacter species or $1411 \mathrm{amu}$, but does contain compounds of 1439 and 1453 amu (Abraham et al., 1997). Positive in tests for the activities of alkaline and acid phosphatase, esterase $\left(\mathrm{C}_{4}\right)$, esterase lipase $\left(\mathrm{C}_{8}\right)$, leucine arylamidase, naphthol-AS-BI-phosphohydrolase and trypsin. Weak activities for cystine arylamidase and $\alpha$ - and $\beta$ glucosidase and no activities for $\alpha$-chymotrypsin, $\alpha$ fucosidase, $\alpha$ - and $\beta$-galactosidase, $\alpha$-glucuronidase, lipase (C14), $N$-acetyl- $\beta$-glucosaminidase, $\alpha$-mannosidase or valine arylamidase. Can utilize $\mathrm{N}$-acetyl-D-glucosamine, D- and L-alanine, asparagine, L-aspartate, aesculin, $\alpha-(+)$ D-glucose, L-glutamate, 3-hydroxybutyrate, DL-lactate, maltose, L-proline, pyruvate, $\alpha$-L-rhamnose, succinate, Lserine and Tween 80 , but not cis- or trans-aconitate, adonitol, 4-aminobutyrate, 5-aminovalerate, $(+)$-L-arabinose, (+)-D- or (-)-L-arabitol, benzoate, betain, caprate, caprylate, $m$-coumarate, $(+)$-D-cellobiose, citrate, dulcitol, i-erythritol, ethanolamine, $\alpha-(+)$-D-fructose, $\alpha$-L-fucose, fumarate, $(+)$-D-galactose, D-galacturonate, $\beta-(+)$-D-gentiobiose, gentisate, D-gluconate, D-glucosamine, D-glucuronate, glutarate, DL-glycerate, glycerol, histamine, Lhistidine, hydroxyquinoline- $\beta$-glucuronide, 3 - or 4 -hydroxybenzoate, myo-inositol, itaconate, 2- or 5-keto-D-gluconate, 2 -ketoglutarate, $\alpha$-lactose, lactulose, $\quad \mathrm{D}$-lyxose, malonate, maltitol, D-mannitol, (+)-D-mannose, $(+)$-Dor $(-)$-L-malate, maltotriose, $(+)$-D-melezitose, $\alpha-(+)$-Dmelibiose, 1-0-methyl- $\alpha$ - and $\beta$-galactopyranoside, 1-0methyl $\alpha$ - and $\beta$-D-glucopyranoside, 3-0-methyl D-glucopyranoside, mucate, palatinose, phenylacetate, 3-phenylpropionate, propionate, protocatechuate, putrescine, quinate, $(+)$-D-raffinose, $(-)$-D-ribose, D-saccharate, D- 
sorbitol, (+)-L-sorbose, sucrose, D-tagatose, $(+)$-L-, $(-)$ D- or meso-tartrate, $(+)$-D-trehalose, tricarballylate, trigonelline, tryptamine, L-tryptophan, L-tyrosine, $(+)$-D-turanose, xylitol or $(+)$-D-xylose. The strain can grow on blood agar or on peptone-yeast extract media with 0 $40 \mathrm{~g} \mathrm{l}^{-1} \mathrm{NaCl}$ with optimal growth between 5 and $20 \mathrm{~g} \mathrm{l}^{-1}$ $\mathrm{NaCl}$. Does not tolerate salt concentrations above $60 \mathrm{~g} \mathrm{l}^{-1}$ $\mathrm{NaCl}$. Growth occurs between 10 and $40{ }^{\circ} \mathrm{C}$, with optimal growth between 20 and $30^{\circ} \mathrm{C}$. No $\mathrm{S}$ layer, but multiple bands of lipopolysaccharides are detected (Walker et al., 1992). The DNA G + C content is $68.0 \mathrm{~mol} \%$.

The type strain, FWC $38^{\mathrm{T}} \quad\left(=\mathrm{CCUG} \quad 55073^{\mathrm{T}}=\mathrm{LMG}\right.$ $24261^{\mathrm{T}}$ ), was isolated from the activated sludge system of a secondary treatment facility, Las Vegas, Nevada, USA.

\section{Acknowledgements}

We thank Jennifer Skerra, Dagmar Wenderoth, Annette Krüger, Carsten Strömpl and Peter Wolff for their excellent technical assistance. Inge Kristen is thanked for her skilful expertise in electron microscopic sample preparation and Dr Edward R. W. Moore for valuable comments. This work was supported by grants of the German Federal Ministry for Science, Education and Research (Project No. 0319433C) and the European Union within the Tproject 'High Resolution Automated Microbial Identification and Application to Biotechnologically Relevant Ecosystems'.

\section{References}

Abraham, W.-R., Meyer, H., Lindholst, S., Vancanneyt, M. \& Smit, J. (1997). Phospho- and sulfolipids as biomarkers of Caulobacter sensu lato, Brevundimonas and Hyphomonas. Syst Appl Microbiol 20, 522-539.

Abraham, W.-R., Strömpl, C., Meyer, H., Lindholst, S., Moore, E. R. B., Bennasar, A., Christ, R., Vancanneyt, M., Tindall, B. \& other authors (1999). Phylogeny and polyphasic taxonomy of Caulobacter species. Proposal of Maricaulis gen. nov. with M. maris (Poindexter) comb. nov. as the type species, and emended description of the genera Brevundimonas and Caulobacter. Int J Syst Bacteriol 49, 1053-1073.

Albuquerque, L., Santos, J., Travassos, P., Nobre, M. F., Rainey, F. A., Wait, R., Empadinhas, N., Silva, M. T. \& da Costa, M. S. (2002). Albidovulum inexpectatum gen. nov., sp. nov., a nonphotosynthetic and slightly thermophilic bacterium from a marine hot spring that is very closely related to members of the photosynthetic genus Rhodovulum. Appl Environ Microbiol 68, 4266-4273.

Altschul, S. F., Gish, W., Miller, W., Myers, E. W. \& Lipman, D. J. (1990). Basic local alignment search tool. J Mol Biol 215, 403-410.

Aslam, Z., Im, W.-T., Ten, L. N. \& Lee, S.-T. (2005). Phenylobacterium koreense sp. nov., isolated from South Korea. Int J Syst Evol Microbiol 55, 2001-2005.

Bellmann, W. \& Lingens, F. (1985). Structural studies on the core oligosaccharide of Phenylobacterium immobile strain K2 lipopolysaccharide. Chemical synthesis of 3-hydroxy-5c-dodecenoic acid. Biol Chem Hoppe Seyler 366, 567-575.

Bligh, E. G. \& Dyer, W. J. (1959). A rapid method for total lipid extraction and purification. Can J Biochem Physiol 37, 911-917.

Henrici, A. T. \& Johnson, D. E. (1935). Studies on fresh water bacteria. II. Stalked bacteria, a new order of schizomycetes. J Bacteriol 30, 61-93.
Kanso, S. \& Patel, B. K. C. (2004). Phenylobacterium lituiforme sp. nov., a moderately thermophilic bacterium from a subsurface aquifer, and emended description of the genus Phenylobacterium. Int J Syst Evol Microbiol 54, 2141-2146.

Kanz, C., Aldebert, P., Althorpe, N., Baker, W., Baldwin, A., Bates, K., Browne, P., van den Broek, A., Castro, M. \& other authors (2005). The EMBL nucleotide sequence database. Nucleic Acids Res 33, D29-D33.

Kumar, S., Tamura, K. \& Nei, M. (2004). MEGA3: integrated software for molecular evolutionary genetics analysis and sequence alignment. Brief Bioinform 5, 150-163.

Lingens, F., Blecher, R., Blecher, H., Blobel, F., Eberspächer, J., Fröhner, C., Görisch, H., Görisch, H. \& Layh, G. (1985). Phenylobacterium immobile gen. nov., sp. nov., a Gram-negative bacterium that degrades the herbicide chloridazon. Int J Syst Bacteriol 35, 26-39.

Löffler, F. (1890). Weitere Untersuchungen über die Beizung und Färbung der Geisseln bei den Bakterien. Zentralbl Bakteriol Parasitenkd 7, 625-639 (in German).

Mesbah, M., Premachandran, U. \& Whitman, W. B. (1989). Precise measurement of the $\mathrm{G}+\mathrm{C}$ content of deoxyribonucleic acid by highperformance liquid chromatography. Int J Syst Bacteriol 39, 159-167.

Neefs, J.-M., Van de Peer, Y., De Rijk, P., Chapelle, S. \& De Wachter, R. (1993). Compilation of small ribosomal subunit RNA structures. Nucleic Acids Res 21, 3025-3049.

Poindexter, J. S. (1964). Biological properties and classification of the Caulobacter group. Bacteriol Rev 28, 231-295.

Poindexter, J. S. (1981). Oligotrophy. Fast and famine existence, pp. 63-89. In Microbial Ecology, vol. 5. Edited by M. Alexander. New York: Plenum Publishing Corp.

Poindexter, J. S. \& Lewis, R. F. (1966). Recommendations for revision of the taxonomic treatment of stalked bacteria. Int J Syst Bacteriol 16, 377-382.

Rüger, H.-J. \& Krambeck, H.-J. (1994). Evaluation of the BIOLOG substrate metabolism system for classification of marine bacteria. Syst Appl Microbiol 17, 281-288.

Segers, P., Vancanneyt, M., Pot, B., Torck, U., Hoste, B., Dewettinck, D., Falsen, E., Kersters, K. \& De Vos, P. (1994). Classification of Pseudomonas diminuta Leifson and Hugh 1954 and Pseudomonas vesicularis Büsing, Döll and Freytag 1953 in Brevundimonas gen. nov. as Brevundimonas diminuta comb. nov. and Brevundimonas vesicularis comb. nov., respectively. Int J Syst Bacteriol 44, 499-510.

Spurr, A. R. (1969). A low viscosity epoxy resin embedding medium for electron microscopy. J Ultrastruct Res 26, 31-43.

Stahl, D. A., Key, R., Flesher, B. \& Smit, J. (1992). The phylogeny of marine and freshwater Caulobacters reflects their habitat. J Bacteriol 174, 2193-2198.

Staley, J. T. (1968). Prosthecomicrobium and Acalomicrobium: new prosthecate freshwater bacteria. J Bacteriol 95, 1921-1942.

Tamaoka, J. \& Komagata, K. (1984). Determination of DNA base composition by reverse-phase high-performance liquid chromatography. FEMS Microbiol Lett 25, 125-128.

Thompson, J. D., Gibson, T. J., Plewniak, F., Jeanmougin, F. \& Higgins, D. G. (1997). The CLUSTAL_X windows interface: flexible strategies for multiple sequence alignment aided by quality analysis tools. Nucleic Acids Res 25, 4876-4882.

Tiago, I., Mendes, V., Pires, C., Morais, P. V. \& Verssimo, A. (2005). Phenylobacterium falsum sp. nov., an alphaproteobacterium isolated from a nonsaline alkaline groundwater, and emended description of the genus Phenylobacterium. Syst Appl Microbiol 28, 295-302.

Urakami, T., Oyanagi, H., Araki, H., Suzuki, K.-i. \& Komagata, K. (1990). Recharacterization and emended description of the genus 
Mycoplana and description of two new species, Mycoplana ramosa and Mycoplana segnis. Int J Syst Bacteriol 40, 434-442.

Vancanneyt, M., Witt, S., Abraham, W.-R., Kersters, K. \& Fredrickson, H. L. (1996). Fatty acid content in whole-cell hydrolysates and phospholipid fractions of pseudomonads: a taxonomic evaluation. Syst Appl Microbiol 19, 528-540.

Walker, S. G., Smith, S. S. \& Smit, J. (1992). Isolation and comparison of the paracrystalline surface layer proteins of freshwater caulobacters. J Bacteriol 174, 1783-1792.

Wilson, K. (1987). Preparation of genomic DNA from bacteria. In Current Protocols in Molecular Biology, pp. 2.4.1-2.4.5. Edited by
F. M. Ausubel, R. Brent, R. E. Kingston, D. D. Moore, J. G. Seidman, J. A. Smith \& K. Struhl. New York: Green Publishing \& WileyInterscience.

Yakimov, M. M., Golyshin, P. N., Lang, S., Moore, E. R. W., Abraham, W.-R., Lünsdorf, H. \& Timmis, K. N. (1998). Alcanivorax borkumensis gen. nov., sp. nov., a new hydrocarbon-degrading and surfactantproducing marine bacterium. Int J Syst Bacteriol 48, 339-348.

Zhang, K., Han, W., Zhang, R., Xu, X., Pan, Q. \& Hu, X. (2007). Phenylobacterium zucineum sp. nov., a facultative intracellular bacterium isolated from a human erythroleukemia cell line K562. Syst Appl Microbiol 30, 207-212. 